\title{
Preferencje ustrojowe jako czynnik dyskrepancyjny identyfikacji ideologicznych i partyjnych
}

System polityczny i determinowane przez niego realia ustrojowe są

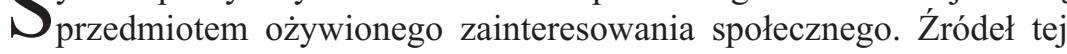
ciekawości poszukiwać można zarówno w chęci zrozumienia sposobów kreowania mechanizmów władczych, jak i możliwości przekładania indywidualnych preferencji w tym względzie na podejmowanie oczekiwanych decyzji politycznych. Społeczne preferencje co do kształtu rozwiązań systemu politycznego są istotną (choć pewnie nie najważniejszą) determinantą wpływającą na podejmowane ustrojowo decyzje. Ich poznanie pozwala nie tylko na nakreślenie palety społecznych oczekiwań, ale daje możliwość ich porównania ze stanem obowiązującym. Wszystkie te czynniki sprawiają, że potrzebnym (w sensie deskryptywnym) i ciekawym (w wymiarze eksplanacyjnym) celem badań empirycznych jest poznanie opinii obywateli na temat wybranych obszarów systemu politycznego oraz umieszczenie ich w szerokim kontekście analitycznym.

Celem prezentowanego tekstu jest analiza ujawnionych w toku badań preferencji ustrojowych w zakresie: reżimu politycznego, systemu partyjnego oraz jednomandatowych okręgów wyborczych na dwóch podstawowych płaszczyznach identyfikacji. Odpowiedzi respondentów zostały przeanalizowane w odniesieniu do ich zadeklarowanych autoidentyfikacji ideologicznych ${ }^{1}$ oraz preferencji partyjnych. Ich rozróżnienie wynika nie tylko z założonego w czasie przygotowania procesu badawczego nastawienia na uzyskanie wyników pogłębionych, ale również badań pilo-

W analizie autoidentyfikacji ideologicznych wykorzystano skalę 11 punktową, gdzie skrajne punkty były oznaczone jako 0 (lewica) oraz 10 (prawica). Środek ciężkości tak skonstruowanej skali stanowi 5 . W prezentowanym materiale poza średnią wskazano również ilościowy i procentowy rozkład poszczególnych kategorii preferencji ustrojowych w układzie: lewica-centrum-prawica, gdzie jako lewicowe deklaracje uznano sumę wskazań od 0 do 4 , jako centrum określono deklaracje środka skali - 5, a jako prawicową orientację sumę wskazań punktów skali 6 do 10 . 
tażowych, które sugerowały istnienie różnic pomiędzy deklarowanymi identyfikacjami ideologicznymi a preferencjami partyjnymi. Badania zostały przeprowadzone w okresie listopad-grudzień 2009 roku na ogólnokrajowej reprezentatywnej próbie dorosłych Polaków, dobranej w sposób kwotowo-warstwowy $(\mathrm{N}=1086)$. Populacja została podzielona w sposób kompletny i rozłączny na warstwy, które stanowią województwa. Procedurą doboru kwotowego objęto następujące zmienne: miejsce zamieszkania (miasto-wieś), płeć i wiek.

Jeżeli chodzi o identyfikację lewicową, to swoistym zaskoczeniem jest fakt, że większym poparciem w tej grupie respondentów cieszy się PO, niż przynajmniej deklaratywnie lewicowe SLD-UP (Tabela 1). Postawy centrowe prawie w połowie sprzyjają $\mathrm{PO}$, a najniższy poziom wskazań przypada PiS (niższy od SLD i PSL). Wśród deklarujących identyfikację prawicową PO i PiS osiagnęły równe poparcie. Poziom wskazań na „inną partię polityczną" jest za każdym razem wyższy niż na mniejsze partie SLD-UP i PSL. Centrum charakteryzuje się również najwyższym poziomem deklarowanej absencji wyborczej.

Tabela 1

Elektoraty wybranych partii w ramach deklarowanych identyfikacji ideologicznych

\begin{tabular}{|c|c|c|c|c|c|c|c|c|}
\hline & Ilość & PO & PiS & SLD & PSL & Inna & $\begin{array}{c}\text { Nie } \\
\text { glosujący }\end{array}$ & Suma \\
\hline & & $\%$ & $\%$ & $\%$ & $\%$ & $\%$ & $\%$ & $\%$ \\
\hline Lewica & 275 & 33,5 & 4,0 & 25,5 & 6,9 & 8,6 & 21,5 & 100 \\
\hline Centrum & 349 & 43,0 & 5,4 & 5,7 & 6,9 & 7,5 & 31,5 & 100 \\
\hline Prawica & 462 & 31,0 & 31,0 & 0,5 & 4,3 & 11,3 & 21,9 & 100 \\
\hline
\end{tabular}

Źródło: Preferencje polityczne 2009, http://www.badaniaelektoratu2009.us.edu.pl/cel.html.

Badanie preferencji społecznych ma na celu również ich porównanie z postulatami programowymi partii politycznych. Program partii politycznej stanowi próbę modelowego ujęcia oczekiwanego ideologicznie i społecznie kształtu rzeczywistości. Ujęcia modelowego, ponieważ odnosi się do znacznego stopnia uogólnień i uproszczeń, dokonywanych w celu tworzenia, w miarę posiadanych możliwości i wiedzy, całościowego obrazu. Opisywana rzeczywistość ma charakter wyidealizowany, gdyż poprzez odwołanie się do kategorii typów idealnych, daje możliwość zaprezentowania pozytywnych (dla potencjalnych odbiorców programu) aspektów 
realizacji proponowanych rozwiązań. Zdaniem A. Downsa ${ }^{2}$, naczelnym imperatywem aktywności politycznej jest zdobycie władzy, w celu osiągnięcia związanych z jej redystrybucją korzyści. Dlatego politycy bardziej formułują programy polityczne w celu zdobycia władzy, niż dążą do niej celem wprowadzenia tychże programów w życie. Pragmatyka polityczna zaś sprawia, że po wygraniu wyborów starają się spełnić możliwie jak najwięcej obietnic wyborczych, gdyż może to zwiększyć ich szanse podczas następnej elekcji. Dlatego też można założyć, że programy partii politycznych bardziej służą wskazywaniu ogólnego kierunku ich przyszłego działania, niźli są agendą planów dotyczących konkretnych zamierzeń. Realizacja tychże zamierzeń jest uzależniona od wielu czynników, z których większość może nie zależeć od samej partii politycznej.

Nie ma wypracowanego jednoznacznego stanowiska wśród politologów co do procesu tworzenia programów politycznych i wyborczych przez partie polityczne oraz wpływu na ten proces zdywersyfikowanych preferencji elektoratu czy też elit partyjnych. Zdaniem Benjamina I. Page to teorie przypisujące partiom formułowanie celów programowych wydają się mieć przewagę nad liczniej występującymi teoriami public opinion ${ }^{3}$. Fakt ten zdaje się być potwierdzany zasadniczą niekompletnością i brakiem koherencji indywidualnych preferencji wyborczych, które wymuszają na partiach politycznych stosowanie strategii segmentacyjnych. $\mathrm{Z}$ drugiej strony, partie nie mogą pozostać głuche na oczekiwania wyborców, co sprawia, że muszą ich postulaty brać pod uwagę przy formułowaniu zapisów programowych.

\section{Reżim polityczny}

Model instytucji władzy wykonawczej jest jednym z wyznaczników kształtu systemu politycznego. Oczywiście nie jest to jedyny czynnik determinujący, ale z pewnością jego rola ma wymiar istotny. Odwołując się

2 T. Michalak, Ekonomiczna teoria demokracji Anthony'ego Downsa, w: Teoria wyboru publicznego. Wstęp do ekonomicznej analizy polityki i funkcjonowania sfery publicznej, red. J. Wilkin, Warszawa 2005, s. 85-86.

B. I. Page, Elekcje a społeczne wybory: teoria i stan badań empirycznych, w: Elity. Demokracja. Wybory, wybór i opracowanie J. Szczupaczyński, Warszawa 1993, s. 159 . 
do pewnych, ogólnych kanonów ustrojowych, możemy mówić o dwóch podstawowych modelach ${ }^{4}$ :

- parlamentarnym (parlamentarno-gabinetowym);

- prezydencjalistycznym.

Odwołanie parlamentarne polega na podporządkowaniu egzekutywy parlamentowi, który doprowadza do jej powołania, ma wpływ na jej skład, przynajmniej pośrednio wpływa na kierunki działania oraz ma możliwość jej odwoływania. To od woli większości parlamentarnej zależeć będzie nie tylko personalny kształt powołanej władzy, ale również charakter relacji pomiędzy nimi oraz zakres realizowanych funkcji władczych (np. w sytuacji kiedy większość parlamentarna torpeduje podejmowane przez egzekutywę działania legislacyjne). W układzie parlamentarno-gabinetowym, który nota bene w wymiarze funkcjonalnym bardzo często obchodzi się bez instytucji prezydenta, rola spełniana przez głowę państwa jest najczęściej mocno ograniczona. Przesunięcie kompetencyjne w zakresie wykonawczym następuje z reguły w kierunku ciała kolegialnego (rząd, gabinet, rada ministrów itp.), którego skład jest w pewnym stopniu odwzorowaniem politycznej większości w parlamencie.

Model prezydencjalistyczny (będący w pewnym, ustrojowym sensie kontrapunktem dla modelu parlamentarnego) zasadza się na przesunięciu większości kompetencji wykonawczych w ręce pochodzącego z powszechnych wyborów prezydenta, przy jednoczesnym założeniu oddzielenia i niezależności pozostałych typów władzy. System taki został początkowo wprowadzony w Stanach Zjednoczonych i pod wpływem amerykańskiego przykładu zastosowany w konstytucjach wielu innych krajów, w pierwszym rzędzie w Ameryce Łacińskiej oraz innych demokracjach powstałych choćby w XX w. ${ }^{5}$ Oczywiście, podobnie jak w przypadku systemu parlamentarno-gabinetowego, prezydencjalizm nie występuje w jednej formie; posiada przynajmniej dwa podstawowe typy (prezydencki i semiprezydencki), w których czynnikiem rozróżniającym jest poziom kompetencji głowy państwa.

W systemie prezydenckim, w którym szerokie kompetencje prezydenta wynikają z ostrego rozdziału władzy ustawodawczej i wykonawczej, a także braku konkurencyjnych ośrodków władzy, skupienie silnej, spersonalizowanej egzekutywy jest wynikiem wysokiej wyborczej legity-

${ }^{4}$ Szerzej: np. A. Antoszewski, R. Herbut, Systemy polityczne współczesnego świata, Gdańsk 2001, s. 310; J. J. Wiatr, Prezydent w systemie demokratycznym, Koszalin 2001, s. 9-12.

${ }^{5}$ Ibidem, s. 10-11. 
mizacji, pochodzącej z powszechnych wyborów. Afiliacja polityczna, identyfikowana najczęściej z poparciem jednej z największych partii, skutkuje szerokim odniesieniem do jej platformy programowej, a sukces wyborczy daje mandat do realizacji celów określonych w kampanii wyborczej. Dodatkowo w tym miejscu można się zastanowić, czy system prezydencki, przynajmniej w sposób pośredni, nie wpływa na koncentrację systemu partyjnego na poziomie parlamentarnym. Nie wchodząc w szczegóły (bo nie tego dotyczy główny przedmiot niniejszego opracowania) wydaje się, że można mówić przynajmniej o domniemaniu występowania takiego związku. Pozycja prezydenta jest dodatkowo podkreślona przez wysoki poziom jego niezależności od innych instytucji władzy: brak politycznej odpowiedzialności przed parlamentem (niemożność skrócenia jego kadencji oraz poza ściśle określonymi konstytucyjnymi regulacjami - brak możliwości zdjęcia z urzędu) oraz przed władzą sądowniczą (najczęściej poprzez posiadanie bardzo szerokiego immunitetu). Dodatkowo prezydent posiada szerokie uprawnienia w zakresie administracyjnym (swobodny dobór swoich współpracowników), a także w sferze polityki zagranicznej (choćby funkcja koordynacyjna i reprezentacyjna) i obronności (np. zwierzchnictwo nad armią) ${ }^{6}$.

Respondenci w przeprowadzonych badaniach opowiadali się za jednym z dwóch systemów rządów: prezydenckim lub parlamentarno-gabinetowym (Tabela 2). Każda z tych opcji była doprecyzowana definicyjnie (odpowiednio: ,jednoosobowa władza wybierana przez obywateli w powszechnych wyborach” oraz „władza w rękach premiera wybieranego

Tabela 2

Zwolennicy różnych typów systemu rządów w perspektywie deklarowanych identyfikacji ideologicznych

\begin{tabular}{||l|c|c|c|c|c|c|c||}
\hline \multirow{2}{*}{} & \multirow{2}{*}{$\begin{array}{c}\text { Średnia na skali } \\
\text { lewica-prawica }\end{array}$} & \multicolumn{2}{|c|}{ Lewica } & \multicolumn{2}{c|}{ Centrum } & \multicolumn{2}{c||}{ Prawica } \\
\cline { 3 - 8 } & 5,63 & 63 & 22,9 & 87 & 24,9 & 131 & 28,4 \\
\hline Prezydenckiego & 5,48 & 122 & 44,4 & 154 & 44,1 & 200 & 43,3 \\
\hline $\begin{array}{l}\text { Parlamentarno- } \\
\text { gabinetowego }\end{array}$ & 5,29 & 90 & 32,9 & 108 & 31,0 & 131 & 28,3 \\
\hline Nie mam zdania & & & 100,0 & & 100,0 & & 100,0 \\
\hline Razem & & & & & & $\mathbf{N}$ & \\
\hline
\end{tabular}

Źródło: Preferencje polityczne 2009, http://www.badaniaelektoratu2009.us.edu.pl/cel.html.

6 W. Wojtasik, Prezydent $w$ demokratycznym modelu ustrojowym, w: Prezydent w Polsce po 1989 r., red. R. Glajcar, M. Migalski, Warszawa 2006, s. 15-17. 
przez Parlament”). Możliwe było również udzielenie odpowiedzi „nie mam zdania". Zwolennicy systemu prezydenckiego na osi lewica-prawica sytuowali się po prawej, w stosunku do osób opowiadających się za systemem parlamentarno-gabinetowym. Nieposiadający zdania byli najbardziej centrowi- najbliżej środka osi.

Zwolennicy systemu parlamentarno-gabinetowego dominują we wszystkich autoidentyfikacjach, w żadnej jednak nie przekraczają połowy. Wśród deklarujących postawy lewicowe stosunkowo najmniej jest zwolenników systemu prezydenckiego, a największy w odniesieniu do reszty odsetek osób nieposiadających zdania.

Wśród wyborców konkretnych partii politycznych, jedynie wśród zwolenników PiS występuje przewaga wskazań systemu prezydenckiego, który ma najmniejsze poparcie wśród wyborców PO oraz osób deklarujących absencję lub chęć głosowania na inną partię. Prawie połowa osób deklarujących absencję nie ma zdania na temat preferowanego systemu rządów (Tabela 3).

Tabela 3

Zwolennicy różnych typów systemu rządów w perspektywie deklarowanych preferencji partyjnych

\begin{tabular}{||c|c|c|c|c|c|c|c|c|c|c|c|c||}
\hline \multirow{2}{*}{} & \multicolumn{2}{|c|}{ PO } & \multicolumn{2}{c|}{ PiS } & \multicolumn{2}{c|}{ SLD-UP } & \multicolumn{2}{c|}{ PSL } & \multicolumn{2}{c||}{ Inna } & \multicolumn{2}{c||}{ Absencja } \\
\cline { 2 - 13 } & $\mathbf{N}$ & $\mathbf{\%}$ & $\mathbf{N}$ & $\mathbf{\%}$ & $\mathbf{N}$ & $\mathbf{\%}$ & $\mathbf{N}$ & $\mathbf{\%}$ & $\mathbf{N}$ & $\mathbf{\%}$ & $\mathbf{N}$ & $\mathbf{\%}$ \\
\hline Prezydencki & 81 & 21,0 & 75 & 43,4 & 26 & 28,0 & 21 & 33,3 & 22 & 21,6 & 56 & 20,7 \\
\hline $\begin{array}{l}\text { Parlamentarno- } \\
\text { gabinetowy }\end{array}$ & 219 & 56,9 & 50 & 28,9 & 50 & 53,8 & 24 & 38,1 & 49 & 48,0 & 84 & 31,2 \\
\hline $\begin{array}{l}\text { Nie mam } \\
\text { zdania }\end{array}$ & 85 & 22,1 & 48 & 27,7 & 17 & 18,2 & 18 & 28,6 & 31 & 30,4 & 130 & 48,1 \\
\hline Razem & & 100,0 & & 100,0 & & 100,0 & & 100,0 & & 100,0 & & 100,0 \\
\hline
\end{tabular}

Źródlo: Preferencje polityczne 2009, http://www.badaniaelektoratu2009.us.edu.pl/cel.html.

\section{System partyjny}

System partyjny to coś więcej niż prosta suma partii politycznych obecnych w przestrzeni rywalizacji politycznej ${ }^{7}$. Jednak w świadomości

7 A. Antoszewski, R. Herbut, Systemy polityczne wspótczesnego świata, Gdańsk 2001, s. 115; R. Herbut, Kategoria systemu partyjnego, w: Wstęp do teorii partii i systemów partyjnych, red. W. Jednak, Poznań 2000, s. 103. 
społecznej funkcjonuje kategoryzacja systemu partyjnego, oparta przede wszystkim na wymiarze ilościowym, którego podstawowym desygnatem jest liczba partii na arenie parlamentarnej, biorących udział w przetargach gabinetowych ${ }^{8}$. W tym wymiarze występuje pewna niedogodność z możliwością wyodrębnienia systemu jednopartyjnego i to nie w kontekście kształtu reżimów niedemokratycznych. Chodzi raczej o nie tak rzadką w państwach demokratycznych sytuację, gdy w systemie partyjnym jedna partia ma wyjątkowo silną pozycję, marginalizując poprzez to pozostałe siły polityczne ${ }^{9}$. Swoista monopartyjność jest więc stanem ograniczenia, bądź wręcz wykluczenia rywalizacyjnych form tworzenia polityki. Dlatego też, na taki stan niektórzy autorzy, zamiast pojęcia system jednopartyjny używają określenia „państwo jednej partii”, znacznie lepiej charakteryzującego naturę opisywanego zjawiska ${ }^{10}$.

System dwupartyjny to taki, w którym dwie partie uzyskują ok. 90\% poparcia, stosunkowo równomiernie rozłożonego pomiędzy obie ${ }^{11}$. Skutkiem tego jest wytworzenie układu odniesienia, w którym sprawują one władze naprzemiennie, a jej alternacja następuje w wyniku zmiany preferencji wyborczych ujawnionych w wyborach powszechnych. Partie w systemie dwupartyjnym odwołują się najczęściej do szerokiego spektrum ideologicznego, chcąc reprezentować w takiej liczbie wyborców, aby ich poparcie zapewniało przejęcie lub utrzymanie władzy. Dlatego partie zaczynają reprezentować typ działania na rynku wyborczym, który bywa nazywany orientacją konsumencką, w ramach którego, jak pisze R. Herbut, następuje proces ukierunkowania działań partyjnych na przekonanie wyborcy niezdecydowanego ${ }^{12}$. W konsekwencji, w systemach dwupartyjnych, następuje proces upodobnienia programów, struktury i sposobów działania głównych aktorów rzeczywistości politycznej, gdyż adresują one część swojej oferty do tego samego wyborcy. W przeciwieństwie do systemów jednopartyjnych, dwupartyjne charakteryzuje niepewność wyborcza co do kierunku dystrybucji władzy, jednak w wyniku decyzji wyborczej, oczywistym staje się kto będzie rządził.

8 W. Sokół, Systemy partyjne, w: Współczesne partie $i$ systemy partyjne, red. W. Sokół, M. Żmigrodzki, Lublin 2003, s. 114-115.

9 K. Sobolewska-Myślik, Partie i systemy partyjne na świecie, Warszawa 2004, s. $105-107$.

10 Ibidem, s. 116.

11 Ibidem, s. 107.

12 R. Herbut, Teoria i praktyka funkcjonowania partii politycznych, Wrocław 2002, s. 94-95. 
Takiej oczywistości nie ma z reguły w systemach wielopartyjnych, gdzie o kierunku dystrybucji władzy decyduje nie tylko wola wyborców wyrażona w akcie głosowania, ale również układ wzajemnych zależności pomiędzy partiami politycznymi. Zdarzają się również, wcale nie tak rzadkie, sytuacje w systemach wielopartyjnych, kiedy jedna partia osiaga większość, pozwalającą rządzić samodzielnie (albo utworzyć gabinet mniejszościowy), lecz nawet $\mathrm{w}$ takich okolicznościach jest to wiadome dopiero po wyborach. Większa liczba partii w systemie sprawia, że zdecydowanie rośnie liczba możliwych aliansów politycznych, których charakter może być zarówno doraźny, jak i długoterminowy, co wpływać może na społeczną ocenę jego stabilności, wynikającą choćby z braku zrozumienia mechanizmów dystrybucji władzy. W zobiektywizowanych kategoriach, liczba partii nie ma znaczenia dla demokratycznej jakości i stabilności systemu partyjnego, gdyż równie demokratyczny może być system dwupartyjny, jak i wielopartyjny spolaryzowany ekstremalnie. Liczba partii i ich relatywny rozmiar to czynniki, które wpływają na identyfikowane wzorce rywalizacji politycznej, proces tworzenia gabinetów koalicyjnych i ich trwałość ${ }^{13}$.

W prezentowanych badaniach respondenci proszeni byli o opowiedzenie się za jednym z systemów partyjnych: jedno-, dwu- lub wielopartyjnym. Odpowiedzi uwzględniały również kategorię „nie mam zdania” (Tabela 4). Wyniki ukazały, że na skali lewica-prawica, najbardziej po prawej stronie lokują się zwolennicy systemu dwupartyjnego, a bliżej centrum - jednopartyjnego. Stosunkowo blisko siebie są admiratorzy wielopartyjności i osoby nie mające zdania, z czego ci ostatni zajmują najbardziej centrowe pozycje.

Tabela 4

Zwolennicy odmiennych typów systemu partyjnego w perspektywie deklarowanych identyfikacji

\begin{tabular}{||l|c|c|c|c|c|c|c||}
\hline \hline & \multirow{2}{*}{$\begin{array}{l}\text { Średnia na skali } \\
\text { lewica-prawica }\end{array}$} & \multicolumn{2}{|c|}{ Lewica } & \multicolumn{2}{c|}{ Centrum } & \multicolumn{2}{c||}{ Prawica } \\
\cline { 3 - 8 } & $\mathbf{N}$ & $\mathbf{\%}$ & $\mathbf{N}$ & $\mathbf{\%}$ & $\mathbf{N}$ & \multicolumn{1}{c||}{} \\
\hline Jednopartyjny & 5,51 & 23 & 8,4 & 29 & 8,3 & 36 & 7,8 \\
\hline Dwupartyjny & 5,83 & 47 & 17,1 & 83 & 23,8 & 139 & 30,1 \\
\hline Wielopartyjny & 5,35 & 135 & 49,1 & 138 & 39,5 & 187 & 40,5 \\
\hline Nie mam zdania & 5,27 & 70 & 25,4 & 99 & 28,4 & 100 & 21,6 \\
\hline Razem & & 100,0 & & 100,0 & & 100,0 \\
\hline
\end{tabular}

Źródlo: Preferencje polityczne 2009, http://www.badaniaelektoratu2009.us.edu.pl/cel.html.

13 R. Herbut, Kategoria systemu..., op. cit., s. 110. 
We wszystkich prezentowanych kategoriach najwięcej jest zwolenników systemu wielopartyjnego i widać dodatkowo, że największa preferencja dla niego występuje po lewej stronie. Największe poparcie systemu dwupartyjnego jest wśród respondentów deklarujących prawicowe przekonania $^{14}$. Około 1/4 badanych w każdej kategorii nie ma preferencji w zakresie kształtu systemu partyjnego.

Tabela 5

Zwolennicy odmiennych typów systemu partyjnego w perspektywie deklarowanych preferencji partyjnych

\begin{tabular}{|c|c|c|c|c|c|c|c|c|c|c|c|c|}
\hline & \multicolumn{2}{|c|}{ PO } & \multicolumn{2}{|c|}{ PiS } & \multicolumn{2}{|c|}{ SLD-UP } & \multicolumn{2}{|c|}{ PSL } & \multicolumn{2}{|c|}{ Inna } & \multicolumn{2}{|c|}{ Absencja } \\
\hline & $\mathbf{N}$ & $\%$ & $\mathbf{N}$ & $\%$ & $\mathbf{N}$ & $\%$ & $\mathbf{N}$ & $\%$ & $\mathbf{N}$ & $\%$ & $\mathbf{N}$ & $\%$ \\
\hline Jednopartyjny & 30 & 7,8 & 17 & 9,8 & 7 & 7,5 & 4 & 6,3 & 11 & 10,8 & 19 & 7,0 \\
\hline Dwupartyjny & 106 & 27,5 & 40 & 23,1 & 22 & 23,7 & 12 & 19,0 & 35 & 34,3 & 54 & 20,0 \\
\hline Wielopartyjny & 176 & 45,7 & 73 & 42,2 & 46 & 49,5 & 29 & 46,1 & 41 & 40,2 & 95 & 35,2 \\
\hline Nie mam zdania & 73 & 19,0 & 43 & 24,9 & 18 & 19,3 & 18 & 28,6 & 15 & 14,7 & 102 & 37,8 \\
\hline Razem & & 100,0 & & 100,0 & & 100,0 & & 100,0 & & 100,0 & & 100,0 \\
\hline
\end{tabular}

Źródło: Preferencje polityczne 2009, http://www.badaniaelektoratu2009.us.edu.pl/cel.html.

W przypadku elektoratów partii politycznych najwięcej zwolenników we wszystkich przypadkach posiada opcja wielopartyjności, osiagając prawie połowę wskazań (Tabela 5). System jednopartyjny cieszy się umiarkowanym poparciem w każdej grupie. Stosunkowo największe poparcie dwupartyjności jest wśród osób wskazujących opcję „,inna partia” co jest o tyle ciekawe, że są to osoby pomijające w swoich preferencjach poparcie największych ugrupowań. Wśród osób deklarujących absencję najwięcej badanych nie posiada zdania w podnoszonej kwestii.

\section{Jednomandatowe okręgi wyborcze}

Rywalizacyjny system wyborczy we współczesnych systemach politycznych postrzegany jest jako warunek sine qua non możliwości mówie-

14 W badaniach przeprowadzanych przez CBOS, na pytanie „Czy uważa Pan(i), że dla kraju lepiej jest, jeżeli:” ponad 60\% badanych wskazało odpowiedź: „nie więcej niż 2-3 partie" (BS/20/2009). Natomiast w badaniach z 2001 roku 44\% respondentów wskazało system dwupartyjny jako najlepszy dla Polski (BS/3/2001) 
nia, o respektowaniu zasad demokracji. Wynika to, przede wszystkim, z przyjęcia zasady powszechnej partycypacji wyborczej, jako modelu nie tyle nawet oczekiwanego, co wręcz niezbędnego dla trwałości i stabilności procedur ustrojowych. Pod pojęciem systemu wyborczego mieści się zespół reguł, które odnoszą się do sposobu wyrażania przez wyborców swoich preferencji, oraz metod transformacji głosów na mandaty przydzielanym rywalizującym ugrupowaniom ${ }^{15}$. W klasycznej formie, zakładającej możliwość biegunowego ukierunkowania, oddziaływanie systemów wyborczych na sferę sytemu politycznego rozpatrywane może być na dwóch płaszczyznach. Pierwszą jest wpływ na system partyjny; jego kształt, charakter rywalizacji wyborczej, model systemu przedstawicielskiego. Druga płaszczyzna obejmuje analizę partycypacji wyborczej, związek pomiędzy wolą społeczną a decyzjami politycznymi, legitymizację reżimu politycznego i ugruntowanie procesów demokratycznych. Właśnie próbie analizy tego drugiego obszaru w kontekście zjawisk związanych pośrednio lub bezpośrednio z procesami demokratyzacyjnymi, dotyczyła ta część badań.

Wychodząc pośrednio z założeń partycypacji politycznej, system wyborczy jest przedstawiany jako część systemu politycznego, który obejmuje reguły określające sposób powoływania organów przedstawicielskich, ich pozycję w aparacie państwowym, ustrojowe zasady określające wzajemne relacje między organami przedstawicielskimi różnych szczebli a wyborcami, oraz charakter wewnętrznej organizacji i tryb działania tych organów. Ponadto system wyborczy na płaszczyźnie politologicznej jest definiowany jako ${ }^{16}$ :

- środek dzięki któremu można w demokracji osiągnąć cele polityczne;

- zbiór zasad i przepisów gry politycznej;

- socjotechniczne formuły, według których głosy wyborców (z uwzględnieniem preferencji i partyjnego członkostwa) przetransponowywane są na mandaty w instytucjach ustawodawczych i wykonawczych;

- praktyczne instrumenty, przez które takie pojęcia jak zgoda i przedstawicielstwo (reprezentacja) są urzeczywistniane;

- proces, przez który preferencje wyborcze są artykułowane w postaci oddanych głosów i przez który głosy są transponowane na przedsta-

15 A. Antoszewski, Ordynacje wyborcze do parlamentu i ich polityczne konsekwencje, w: Ewolucja polskiego systemu politycznego po 1989 roku w świetle komparatystycznej teorii polityki, red. A. Antoszewski, Wrocław 1995, s. 42.

16 A. Żukowski, Systemy wyborcze, Olsztyn 2003, s. 51-52. 
wicieli władzy rządowej spośród konkurujących ze sobą partii politycznych $^{17}$.

Podział na okręgi wyborcze, w uproszczeniu spełnia 3 funkcje. Po pierwsze, zapewnia równą reprezentację poszczególnym częściom kraju. Po drugie, zapewnia bardziej „spersonalizowany” charakter wyborów, szczególnie w stosunku do sytuacji, gdyby taki podział nie funkcjonował. Wreszcie struktura okręgów jest istotnym parametrem dla formuł wyborczych. Formuły większościowe, z założenia przyznają preferencję dla okręgów jednomandatowych. W formułach quasi proporcjonalnych efektywnie górna liczba mandatów w okręgu wynosi 5, zaś dla systemów proporcjonalnych nie ma ograniczenia liczby mandatów w okręgu ${ }^{18}$. W Polsce, realna dyskusja nad kształtem systemu wyborczego bardzo często jest zastępowana przez swoistą protezę, w postaci nawoływań do wprowadzenia jednomandatowych okręgów wyborczych ${ }^{19}$.

Respondenci proszeni byli o wyrażenie swojej akceptacji dla sytuacji wprowadzenia jednomandatowych okręgów wyborczych w Polsce (Tabela 6). Badani mieli również możliwość niewyrażenia zdania w tej kwestii. Wyniki ukazują, że zwolennicy jednomandatowych okręgów wyborczych są nieco bardziej prawicowi niż ich przeciwnicy. Osoby niemające w tej kwestii zdania lokują się pomiędzy nimi.

Tabela 6

Zwolennicy i przeciwnicy jednomandatowych okręgów wyborczych w perspektywie deklarowanych identyfikacji ideologicznych

\begin{tabular}{|c|c|c|c|c|c|c|c|}
\hline & \multirow{2}{*}{$\begin{array}{l}\text { Średnia na skali } \\
\text { lewica-prawica }\end{array}$} & \multicolumn{2}{|c|}{ Lewica } & \multicolumn{2}{|c|}{ Centrum } & \multicolumn{2}{|c|}{ Prawica } \\
\hline & & $\mathbf{N}$ & $\%$ & $\mathbf{N}$ & $\%$ & $\mathbf{N}$ & $\%$ \\
\hline Tak & 5,54 & 99 & 36,0 & 110 & 31,5 & 186 & 40,3 \\
\hline $\mathrm{Nie}$ & 5,27 & 64 & 23,3 & 63 & 18,0 & 73 & 15,8 \\
\hline Nie mam zdania & 5,48 & 112 & 40,7 & 176 & 50,5 & 203 & 43,9 \\
\hline Razem & & & 100,0 & & 100,0 & & 100,0 \\
\hline
\end{tabular}

Źródło: Preferencje polityczne 2009, http://www.badaniaelektoratu2009.us.edu.pl/cel.html.

17 W. Wojtasik, Rola systemów wyborczych i partycypacji wyborczej w procesach demokratyzacji, w: System międzynarodowy. Koncepcje, wyzwania, perspektywy, red. A. Wentkowska, M. Kaczmarczyk, Sosnowiec 2005, s. 20-21.

18 J. Haman, Demokracja. Decyzje. Wybory, Warszawa 2003, s. 75-76.

19 Instytucjonalną formułą takich preferencji jest Ruch Obywatelski na rzecz wprowadzenia Jednomandatowych Okręgów Wyborczych. Więcej: http:/www.jow.pl/. 
Jednomandatowe okręgi wyborcze są czynnikiem słabo różnicującym autoidentyfikację, gdyż prawie połowa respondentów nie ma na ten temat zdania. Wśród pozostałych, we wszystkich wyróżnionych grupach występuje przewaga zwolenników jednomandatowych okręgów wyborczych, z tym, że na prawicy jest ona największa.

Wśród elektoratów największych partii, jedynie wśród zwolenników SLD-UP jest więcej przeciwników jednomandatowych okręgów wyborczych, choć w przypadku PSL zwolenników jest niewiele więcej niż osób przeciwnych (Tabela 7). Również w SLD-UP najmniejsza jest grupa niezdecydowanych, choć niewiele więcej jest ich wśród deklarujących głosowanie na ,inną" partię. Zdecydowanie najwięcej niezdecydowanych jest w grupie deklarujących absencję wyborczą.

Tabela 7

Zwolennicy i przeciwnicy jednomandatowych okręgów wyborczych w perspektywie deklarowanych preferencji partyjnych

\begin{tabular}{|l|r|c|c|c|c|c|c|c|c|c|c|c||}
\hline \multirow{2}{*}{} & \multicolumn{2}{|c|}{ PO } & \multicolumn{2}{c|}{ PiS } & \multicolumn{2}{c|}{ SLD-UP } & \multicolumn{2}{c|}{ PSL } & \multicolumn{2}{|c|}{ Inna } & \multicolumn{2}{c|}{ Absencja } \\
\cline { 2 - 13 } & $\mathbf{N}$ & $\mathbf{\%}$ & $\mathbf{N}$ & $\mathbf{\%}$ & $\mathbf{N}$ & $\mathbf{\%}$ & $\mathbf{N}$ & $\mathbf{\%}$ & $\mathbf{N}$ & $\mathbf{\%}$ & $\mathbf{N}$ & $\mathbf{\%}$ \\
\hline Tak & 172 & 44,7 & 52 & 30,1 & 29 & 31,2 & 16 & 25,4 & 48 & 47,0 & 78 & 28,9 \\
\hline Nie & 59 & 15,3 & 38 & 22,0 & 35 & 37,6 & 15 & 23,8 & 21 & 20,6 & 32 & 11,9 \\
\hline $\begin{array}{l}\text { Nie mam } \\
\text { zdania }\end{array}$ & 154 & 40,0 & 83 & 47,9 & 29 & 31,2 & 32 & 50,8 & 33 & 32,4 & 160 & 59,2 \\
\hline Razem & & 100,0 & & 100,0 & & 100,0 & & 100,0 & & 100,0 & & 100,0 \\
\hline
\end{tabular}

Źródło: Preferencje polityczne 2009, http://www.badaniaelektoratu2009.us.edu.pl/cel.html.

\section{Wnioski}

Przytoczone powyżej wyniki badań wskazuja, że preferencje społeczeństwa w zakresie rozwiązań ustrojowych, nie odbiegają znacząco od stanu faktycznego. W przypadku systemu rządów, największa grupa respondentów opowiada się za modelem parlamentarno-gabinetowym, co stanowi również swoistą odpowiedź na toczącą się w Polsce dyskusję, dotyczącą rewizji rozwiązań przyjętych na gruncie Konstytucji z 1997 roku. Podobnie ma się sprawa z preferencjami dotyczącymi formatu systemu partyjnego, w ramach których największa grupa badanych opowiedziała się po stronie systemu wielopartyjnego. Nieco inaczej wygląda stosunek do jednomandatowych okręgów wyborczych, gdyż w tym przypadku, największa grupa ankietowanych nie miała zdania na ten temat, a wśród je wyrażających występowała preferencja dla ich istnienia. 
W przeprowadzonych analizach dokonano również diagnozy istotności różnic pomiędzy grupami opowiadającymi się za szczegółowymi rozwiązaniami, które były przedmiotem badania. Istotność różnic w ramach wskazań admiratorów badanych opcji na skali lewica-prawica pokazuje, czy zwolennicy poszczególnych rozwiązań wykazują względem siebie istotne zróżnicowanie statystyczne, które nie wynika z samych wartości na skali. Dla ich zbadania zastosowano test-T dla prób niezależnych, przeprowadzony dla trzech kwestii podnoszonych w niniejszym opracowaniu.

Tabela 8

Istotność różnic w zakresie systemu rządów

\begin{tabular}{|c|c|c|c|}
\hline System rządów & t & $d f$ & $\mathbf{p}$ \\
\hline Zwolennicy systemu prezydenckiego & \multirow[t]{2}{*}{1,008} & \multirow[t]{2}{*}{523,604} & \multirow[t]{2}{*}{ n.i. } \\
\hline Zwolennicy systemu parlamentarno-gabinetowego & & & \\
\hline Zwolennicy systemu prezydenckiego & \multirow[t]{2}{*}{1,837} & \multirow[t]{2}{*}{605} & \multirow[t]{2}{*}{ n.i. } \\
\hline Nie mam zdania & & & \\
\hline Zwolennicy systemu parlamentarno-gabinetowego & \multirow[t]{2}{*}{1,179} & \multirow[t]{2}{*}{583,853} & \multirow[t]{2}{*}{ n.i. } \\
\hline Nie mam zdania & & & \\
\hline
\end{tabular}

W zakresie systemu rządów różnice pomiędzy poszczególnymi grupami okazały się nieistotne statystycznie.

Tabela 9

Istotność różnic w zakresie ksztaltu systemu partyjnego

\begin{tabular}{|c|c|c|c|}
\hline System partyjny & $\mathbf{t}$ & $d f$ & $\mathbf{p}$ \\
\hline Zwolennicy systemu jednopartyjnego & \multirow[t]{2}{*}{$-1,106$} & \multirow[t]{2}{*}{122,697} & \multirow[t]{2}{*}{ n.i. } \\
\hline Zwolennicy systemu dwupartyjnego & & & \\
\hline Zwolennicy systemu jednopartyjnego & \multirow[t]{2}{*}{, 565} & \multirow[t]{2}{*}{108,143} & \multirow[t]{2}{*}{ n.i. } \\
\hline Zwolennicy systemu wielopartyjnego & & & \\
\hline Zwolennicy systemu jednopartyjnego & \multirow[t]{2}{*}{,862 } & \multirow[t]{2}{*}{355} & \multirow[t]{2}{*}{ n.i } \\
\hline Nie mam zdania & & & \\
\hline Zwolennicy systemu dwupartyjnego & \multirow[t]{2}{*}{3,228} & \multirow[t]{2}{*}{727} & \multirow[t]{2}{*}{, 001} \\
\hline Zwolennicy systemu wielopartyjnego & & & \\
\hline Zwolennicy systemu dwupartyjnego & \multirow[t]{2}{*}{3,113} & \multirow[t]{2}{*}{518,903} & \multirow[t]{2}{*}{,002 } \\
\hline Nie mam zdania & & & \\
\hline Zwolennicy systemu wielopartyjnego & \multirow[t]{2}{*}{, 543} & \multirow[t]{2}{*}{486,899} & \multirow[t]{2}{*}{ n.i. } \\
\hline Nie mam zdania & & & \\
\hline
\end{tabular}


W przypadku systemu partyjnego istotne statystycznie różnice występowały pomiędzy zwolennikami systemu dwupartyjnego a osobami opowiadającymi się za systemem wielopartyjnym i niezdecydowanymi. Zwolennicy dwupartyjności byli istotnie bardziej prawicowi. Fakt ten można próbować interpretować poprzez przyjrzenie się ideologicznemu charakterowi dwóch największych partii, których wymiar genetyczny i programowy sytuuje je po prawej stronie sceny politycznej.

Tabela 10

Istotność różnic w zakresie jednomandatowych okręgów wyborczych

\begin{tabular}{|c|c|c|c|}
\hline Jednomandatowe okręgi wyborcze & t & $d f$ & $\mathbf{p}$ \\
\hline Zwolennicy jednomandatowych okręgów wyborczych & \multirow[t]{2}{*}{1,455} & \multirow[t]{2}{*}{593} & \multirow[t]{2}{*}{ n.i. } \\
\hline Przeciwnicy jednomandatowych okręgów wyborczych & & & \\
\hline Zwolennicy jednomandatowych okręgów wyborczych & \multirow[t]{2}{*}{487} & \multirow[t]{2}{*}{879} & \multirow[t]{2}{*}{ n.i. } \\
\hline Nie mam zdania & & & \\
\hline Przeciwnicy jednomandatowych okręgów wyborczych & \multirow[t]{2}{*}{$-1,141$} & \multirow[t]{2}{*}{684} & \multirow[t]{2}{*}{ n.i. } \\
\hline Nie mam zdania & & & \\
\hline
\end{tabular}

W przypadku jednomandatowych okręgów wyborczych nie wykazano istotnych statystycznie różnic wśród zwolenników poszczególnych opcji.

\section{Bibliografia}

Antoszewski A., Ordynacje wyborcze do parlamentu i ich polityczne konsekwencje, w: Ewolucja polskiego systemu politycznego po 1989 roku w świetle komparatystycznej teorii polityki, red. A. Antoszewski, Wydawnictwo Uniwersytetu Wrocławskiego, Wrocław 1995.

Antoszewski A., Herbut R., Systemy polityczne współczesnego świata, Wydawnictwo Arche, Gdańsk 2001.

Ewolucja polskiego systemu politycznego po 1989 roku w świetle komparatystycznej teorii polityki, red. A. Antoszewski, Wydawnictwo Uniwersytetu Wrocławskiego, Wrocław 1995.

Haman J., Demokracja. Decyzje. Wybory, Wydawnictwo Naukowe Scholar, Warszawa 2003.

Herbut R., Kategoria systemu partyjnego, w: Wstęp do teorii partii i systemów partyjnych, red. W. Jednaka, Wydawnictwo Terra, Poznań 2000.

Herbut R., Teoria i praktyka funkcjonowania partii politycznych, Wydawnictwo Uniwersytetu Wrocławskiego, Wrocław 2002. 
Michalak T., Ekonomiczna teoria demokracji Anthony'ego Downsa, w: Teoria wyboru publicznego. Wstęp do ekonomicznej analizy polityki i funkcjonowania sfery publicznej, red. J. Wilkin, Wydawnictwo Naukowe Scholar, Warszawa 2005.

Page B. I., Elekcje a społeczne wybory: teoria i stan badań empirycznych, w: Elity. Demokracja. Wybory, wybór i opracowanie J. Szczupaczyński, Wydawnictwo Naukowe Scholar, Warszawa 1993.

Sobolewska-Myślik K., Partie i systemy partyjne na świecie, Wydawnictwo Naukowe PWN, Warszawa 2004.

Sokół W., Systemy partyjne, w: Współczesne partie i systemy partyjne, red. W. Sokół, M. Żmigrodzki, Wydawnictwo UMCS, Lublin 2003.

System międzynarodowy. Koncepcje, wyzwania, perspektywy, red. A. Wentkowska, M. Kaczmarczyk, Wydawnictwo WSZiM, Sosnowiec 2005.

Teoria wyboru publicznego. Wstęp do ekonomicznej analizy polityki i funkcjonowania sfery publicznej, red. J. Wilkin, Wydawnictwo Naukowe Scholar, Warszawa 2005.

Wiatr J. J., Prezydent $w$ systemie demokratycznym, Wydawnictwo WSAiP, Koszalin 2001.

Wojtasik W., Rola systemów wyborczych i partycypacji wyborczej w procesach demokratyzacji, w: System międzynarodowy. Koncepcje, wyzwania, perspektywy, red. A. Wentkowska, M. Kaczmarczyk, Wydawnictwo WSZiM, Sosnowiec 2005.

Wojtasik W., Prezydent $w$ demokratycznym modelu ustrojowym, w: Prezydent w Polsce po 1989 r., red. R. Glajcar, M. Migalski, Wydawnictwo Sejmowe, Warszawa 2006.

Wstęp do teorii partii i systemów partyjnych, red. W. Jednaka, Wydawnictwo Terra, Poznań 2000.

Żukowski A., Systemy wyborcze, Wydawnictwo Uniwersytetu Warmińsko-Mazurskiego, Olsztyn 2003.

\section{Summary}

Apart from its institutional dimensions, the determining factors of the evolution of a political system are based on the social expectations concerning the possible shape of the preferred and implemented solutions. This paper presents the conclusions of nationwide research carried out on a representative sample $(\mathrm{N}=1086)$ to analyze the direction and scope of the expected change in the political system in relation to the political programs of the main political parties in Poland. 
